\title{
AS PRISÕES DO MERCADO
}

\author{
LAURINDO DIAS MINHOTO
}

Já se observou certa vez que as sólidas muralhas das casas de detenção constituem o ideal impiedoso da civilização burguesa fixado em pedra. Destoando do teatro do suplício protagonizado pela penalidade característica da transição do medievo à modernidade, a sóbria penitenciária, ao infligir no corpo e na alma dos condenados as marcas do ritmo monótono do trabalho, mimetiza por assim dizer a disciplina e os rigores necessários à sociedade fabril, delineando portanto o espectro terrível da existência do homem moderno num mundo crescentemente administrado: "o homem na penitenciária é a imagem virtual do tipo burguês em que ele deve se transformar na realidade." Daí que os recalcitrantes do lado de fora das grades serão devidamente enquadrados, numa terrível pureza, do lado de dentro. Exatamente por isso, justificar a existência de penitenciárias com a necessidade de separar o criminoso da sociedade, ou mesmo de regenerá-lo, não atinge o âmago da questão, já que elas constituem antes "a imagem do mundo do trabalho burguês levado às últimas consequiências, imagem essa que o ódio dos homens coloca no mundo como um símbolo contra a realidade em que são forçados a se transformar."1

À medida que a sociedade vai se convertendo mais e mais numa autêntica prisão ao ar livre — brutalmente escancarada a partir do experimento fascista, com seus campos de trabalho forçado e de extermínio em massa - a penitenciária paulatinamente tenderia a se tornar algo como um artigo de luxo, uma lembrança dos bons velhos tempos, uma vez que

1 Th. Adorno e M. Horkheimer, "Fragmento de uma teoria do criminoso", in Dialética do Esclarecimento. Rio de Janeiro: Jorge Zahar, 1985, pp. 211-212. 
"a pena de privação de liberdade parece um pálido castigo se comparada à realidade social."2 Esta formulação pressupõe, por certo, uma distinção entre um sistema prisional administrado em bases minimamente legais e racionais e o puro terror dos campos de concentração. Noutros termos, uma distinção entre o genocídio e a dominação mediada pelo direito. Entretanto, à proporção que o adestramento vai se instilando no sangue e na carne dos indivíduos, configurando a personalidade autoritária que institui o eu de cada um como uma espécie de Führer introjetado, a penitenciária, ao se realizar plenamente no corpo social, perderia a sua razão de ser. A esse respeito, basta consultar o que dizem aqui e ali os próprios detentos para verificar o acerto do diagnóstico materialista, que, aliás, em tempo de horror econômico, parece estar valendo hoje mais do que nunca. Se isto é assim, porém, como entender então o retorno do grande encarceramento, a atual voga de expansão vertiginosa do sistema penitenciário que varre algumas das principais nações capitalistas do globo, Estados Unidos e GrãBretanha à frente, que, precisamente num contexto de crise fiscal e aperto orçamentário, não hesitam em destinar uma massa impressionante de recursos à rubrica law and order, prisões em primeiríssimo lugar? Volta aos bons velhos tempos, sob os influxos da dobradinha democracia e mercado, vazada retoricamente nos termos capengas de uma gelatinosa terceira via? Definitivamente, não é o que parece.

\section{GRANDE NEGÓCIO}

Mais de 650 empresas participaram na Flórida do "Congresso de Orlando", ocorrido em agosto de 1997 sob o patrocínio da Associação Correcional Americana, organismo privado fundado em 1870, que promove os interesses do setor. Na vitrine, entre outros artigos expostos pelos novos "industriais do encarceramento", algemas acolchoadas e armas de fogo, cadeados e grades indevassáveis, mobiliário para as celas, artigos variados de perfumaria e alimentação, cadeiras imobilizantes e "uniformes de extração" (destinados a arrancar detentos recalcitrantes de suas celas), grelhas eletrificadas de efeito letal, programas de desintoxicação para drogados ou de "rearmamento moral" para jovens delinqüentes, sistemas de

2 Adorno e Horkheimer, loc. cit. 
supervisão eletrônica e de telefonia de última geração, tecnologias biométricas de detecção e identificação, pacotes de gestão informatizada de dados administrativos e judiciários, sem falar nas celas desmontáveis e nas prisões "chave-na-mão". 3

As duas maiores companhias envolvidas no atual negócio das prisões administram estabelecimentos penitenciários nos EUA, Canadá, Inglaterra, França, Alemanha, Austrália e Porto Rico. A Corrections Corporation of America (CCA) e a Wackenhut Corrections Corporations detêm 3/4 do mercado global das prisões. O market share das duas companhias corresponde a $49,32 \%$ e $25,81 \%$, respectivamente. Segundo suas previsões, num futuro próximo ambas deveriam expandir os negócios rumo à América Latina e ao Leste Europeu. As recentes visitas de autoridades do Panamá, México, Argentina e Chile a alguns de seus estabelecimentos "dão uma medida significativa do enorme potencial de expansão do mercado global dos serviços de administração penitenciária". Em junho de 1996, enquanto a média anual do índice Dow Jones girava em torno de $11 \%$, as ações da CCA virtualmente dobraram o seu valor e as da Wackenhut valorizaram-se em nada mais nada menos que $155 \%$, o que levou Wall Street a considerá-las uma ótima opção de investimento (hot stocks). ${ }^{4}$

Essa promissora indústria, apenas na esfera das cadeias locais norte-americanas, movimentou algo como US\$ 65 bilhões no ano de 1994. Leia-se a respeito o convite estampado em catálogo da Associação Americana das Cadeias Locais para conferência de treinamento e exposição de produtos, negócios e oportunidades ocorrida em maio de 1994, em Indiana:

“Expo Prisão 1994: Participe do mercado de US\$ 65 bilhões das cadeias locais.

O público-alvo da "Expo Prisão" é constituído por tomadores de decisão na área das prisões locais — xerifes dos condados, administradores de estabelecimentos correcionais, autoridades locais, diretores de serviços médicos e alimentares, arquitetos, engenheiros — pessoas de todos os pontos do país envolvidas em questões relativas à administração de cadeias

3 Cf. Loic Wacquant, "Boom des pénitenciers privés", Le Monde Diplomatique, julho de 1998, p. 20.

4 Cf. Prison Privatisation Report International (PPRI), nos. 2, 3, 6 e 7, Londres, Prison Reform Trust's Publications, Julho e Agosto de 1996 e Janeiro e Fevereiro de 1997, respectivamente. 
locais, novos produtos, serviços e tendências. Existem mais de 100.000 pessoas que trabalham nas quase 3.400 cadeias locais dos Estados Unidos. Apenas no ano passado mais de US\$ 65 bilhões foram movimentados por essa indústria. O mercado das cadeias locais é muito lucrativo! Cadeias são um GRANDE NEGÓCIO".

E o programa de uma conferência patrocinada pelo Instituto Nacional de Justiça dos EUA, ocorrida em junho do mesmo ano:

\section{TECNOLOGIA DE APLICAÇÃO DA LEI PARA O SÉCULO XXI: A ALTERNATIVA NÃO-LETAL}

Objetivos da conferência:

aguçar a percepção quanto às demandas da aplicação da lei; entender a importância do valor tecnológico incorporado à aplicação da lei;

destacar as oportunidades de transferência de tecnologia para a indústria de defesa;

enfatizar as oportunidades industriais no mercado da aplicação da lei". 5

Em tempo de capitalismo turbinado, altos índices de produtividade, desemprego estrutural e insegurança generalizada, o cárcere constitui um dos mais prósperos vetores a impulsionar a formação de uma florescente indústria de combate à criminalidade. Na dinâmica instaurada pela "nova economia", a prisão se converte em meio de controle altamente lucrativo das ilegalidades dos perdedores globais. Não por acaso, sob os escombros do Welfare State, vem se erigindo um vigoroso Estado Penal, cujo dínamo repousa exatamente no gerenciamento empresarial dos novos sujeitos monetários sem dinheiro 6 que, uma vez descartados da nova ordem econômica internacional, são reinseridos nas prisões do mercado na qualidade de consumidores cativos da indústria da punição. Noutros termos, a sociedade sem trabalho do capitalismo fin-de-siè-

5 Nils Christie, Crime Control as Industry: Towards Gulags, Western Style. Londres: Routledge, 1994, pp. 193-194.

6 Tomo a fórmula de empréstimo a R. Kurz, que a cunhou nos seguintes termos: "a maioria da população mundial já consiste hoje de sujeitos monetários sem dinheiro, pessoas que não se encaixam em nenhuma forma de organização social, nem na pré-capitalista, nem na capitalista, e muito menos na pós-capitalista, sendo forçadas a viver num leprosário social que já compreende a maior parte do planeta”. O Colapso da Modernização. Rio de Janeiro: Paz e Terra, 1996, p. 195. 
cle parece requerer a manutenção da velha prática do gulag - só que agora Western style, bem entendido - , para preservar a parede de vidro que por enquanto continua a proteger o festim dos animais maravilhosos. ${ }^{7}$

Essa nova configuração sem dúvida pode dar o que pensar: e se por exemplo a parede de vidro que hoje protege "os de cima" e segrega "os de baixo" for do mesmo blindex produzido pela mesma indústria bilionária que fatura com o admirável mundo novo das tecnologias da informação e que provê indiferentemente os gadgets que monitoram com rigor e minúcia os passos dos de dentro e dos de fora da prisão? E se os condomínios de luxo se parecerem mais e mais com as velhas fábricas cercadas (um antigo e novíssimo sinônimo para o cárcere), a abrigar o fluxo incessante dos novos servos e os novos senhores do silício - amedrontados, e com razão - em face da dinâmica capilarizada assumida pela nova guerra civil? E se a crescente brasilianização das sociedades ditas avançadas, que tende a emparedar os integrados e a instaurar um controle de tipo militar sobre os setores cada vez mais amplos dos descontentes, demandar uma privatização possessiva da justiça em escala global, ramo em que certamente detemos expertise de ponta? E se o neojaguncismo chique e high-tech, agora impulsionado pela jaula de ferro da mercadoria, reencontrar o capataz do enclave fortificado na figura pouco provável do diligente policial que faz mais um bico para descolar um extra?

Vê-se por aí que o atual processo de mercantilização da esfera penitenciária não poderia deixar de colecionar sobressaltos. É mesmo para desnortear, e talvez, em especial, ao jurista formado na tradição liberal, humanitária e iluminista mais exigente. Como dimensionar, por exemplo, tamanho potencial de expansão do sistema no limiar do terceiro milênio, após gloriosos lustros de altissonante pregação anticarcerária? O que poderia significar exatamente a conversão do sistema penitenciário em indústria e das prisões num vigoroso "mercado da aplicação da lei", à luz da catadupa de alentados tratados, do progresso da ciência jurídica e da cantilena da

\footnotetext{
7 Na ferina observação de Iná Camargo Costa, ganha-se assim nas duas pontas da atual corrida ao corte de custos, desempregando de um lado e encarcerando de outro, o que sem dúvida assinala "um avanço em relação a Auschwitz (...) uma vez que lá a exploração do trabalho escravo e a indústria do genocídio precisaram da mediação do Estado, entrando na coluna dos custos. Agora é investimento lucrativo sem intermediários: entre outros ganhos de produtividade, houve simplificação na própria contabilidade", nota da digitação incluída em "Documentos de cultura, documentos de barbárie. O sujeito oculto de um manifesto", ensaio de Paulo Arantes preparado para a revista do grupo teatral Folias D'Arte.
} 
sempre prometida autonomia do direito e do pensamento jurídico, cuja racionalidade deveria ter instaurado uma práxis criminológica progressista? Se não quisermos proceder à maneira do Barão de Münchhausen que imaginava poder sair do atoleiro puxando pelos próprios cabelos -, insistindo à outrance numa autonomia crescentemente quimérica, nem tampouco ao modo dos conservadores, condenando in totum e de forma simplista o andamento das coisas e brandindo o sempiterno quebra-galho fiat jus et pereat mundus, parece-me que o momento está a exigir reflexão. Antes de mais nada, trata-se de divisar no sistema penitenciário e nas múltiplas determinações que o configuram uma plataforma privilegiada de observação da cena contemporânea.

\section{A PROMESSA}

A superpopulação penitenciária e os custos crescentes do encarceramento são as principais razões invocadas pelos governos norte-americano e britânico para justificar a adoção de uma política sistemática de privatização de presídios a partir dos anos 80. Nos EUA, a população penitenciária cresceu $250 \%$ desde 1950 . Apenas no período compreendido entre 1976 e 1986 ela mais que dobrou. Atualmente, um em cada 350 norte-americanos está atrás das grades e nada menos que 2,8\% da população adulta do país vivem sob algum tipo de supervisão penal. Entre 1982 e 1992, o gasto do governo norte-americano com o sistema penitenciário subiu 248\%. Na Grã-Bretanha, havia em 1987 mais gente presa do que em qualquer outro país da Europa ocidental, à exceção da Turquia. Em 1997, a população penitenciária britânica alcança a impressionante marca dos 60 mil detentos e uma taxa de encarceramento da ordem dos 116 prisioneiros por 100 mil habitantes, comparada aos 29 por 100 mil de 1923 e aos 32 por 100 mil dos anos 30. Entre 1976 e 1996, o gasto do governo britânico com o sistema penitenciário subiu de 163 milhões para 1,5 bilhão de libras esterlinas.

Em face da superpopulação, não é de espantar que as condições de alojamento dos detentos venha se degradando a largos passos. Parece haver consenso na descrição das quase 5 mil prisões e cadeias locais norteamericanas como superpovoadas, violentas e improdutivas. Na GrãBretanha, estima-se hoje em pelo menos 16 mil o número de prisioneiros alojados em condições subumanas, trancafiados em grupos de três ou mais em cubículos originariamente concebidos para um detento, por até 23 
horas diárias. Nesse cenário, os conflitos entre os detentos, assim como as rebeliões, constituem uma segunda natureza.

Para além das distinções que informam seus sistemas de justiça criminal, pode-se dizer que um ingrediente chave da crise do sistema carcerário contemporâneo é a redução economicista da questão penitenciária empreendida pelas sucessivas administrações norte-americana e britânica, influindo no modo como são encaminhadas as propostas supostamente destinadas aos seu enfrentamento. Uma crise concebida primordialmente em termos físicos e monetários, em que em nenhum momento se problematiza o papel da prisão enquanto mecanismo de controle social e sua complexa vinculação ao problema da criminalidade é acriticamente pressuposta. Um exemplo emblemático de transposição de agendas, no caso, da conservadora para os programas democrata e trabalhista nos dois lados do Atlântico. Não é à toa que a resposta desses governos à crise prisional tem sido bem óbvia: more of the same. Ambos detonaram os maiores programas de construção de presídios de sua história.

Assim é que a política de privatização de presídios foi proposta como uma espécie de panacéia destinada a driblar os gargalos do sistema penitenciário. Nas palavras de seu sócio fundador, Thomas Beasley, proprietário de terras e investidor no ramo de seguros, a Corrections Corporation of America foi estabelecida em 1983 para "resolver a questão penitenciária e fazer um bom dinheiro". Em termos bastante esquemáticos, a empresa propõe-se muito modestamente a oferecer aos Estados fórmulas alternativas de financiamento da construção de novos estabelecimentos, adotar técnicas de gestão empresarial na administração das prisões e, sobretudo, enfrentar a superpopulação de maneira a criar condições propícias a uma efetiva reabilitação dos detentos. Segundo o catálogo promocional da CCA, "aliar os padrões mais elevados da penitenciária aos princípios comprovados da livre iniciativa." ${ }^{\mathrm{Na}} \mathrm{Grã-Bretanha,} \mathrm{o} \mathrm{Instituto} \mathrm{Adam}$ Smith, um think-tank da direita, invocando a ineficácia das instituições prisionais e os altos custos do encarceramento - "três vezes superior às taxas cobradas pelas mais caras public schools" —, publica em 1984 o "Relatório Ômega", recomendando a adoção das prisões privadas e fazendo expressa referência à experiência norte-americana. Nos termos do relatório, "empresas de segurança e operações hoteleiras são ambas práti-

8 R. P. Weiss, "Private prisons and the state", in R. Matthews (ed) Privatizing Criminal Justice. Londres: Sage, pp. 29-30. 
ca corrente no âmbito do setor privado; pode até ser uma simplificação, mas uma prisão envolve apenas um pouco mais que uma combinação dessas duas atividades." 9

A experiência norte-americana concreta no campo dos novos negócios correcionais tem se revelado, no entanto, bastante desigual: (a) a face mais ousada do processo, o nec plus ultra da administração privada total de estabelecimentos penitenciários, tem sido bem menos utilizada que outras modalidades de privatização; (b) ela vem se concentrando na "ponta leve" do sistema, sobretudo nos setores de imigrantes e de jovens criminosos, em que a parafernália securitária habitual pode ser dispensada; (c) no que diz respeito ao alojamento de adultos, ela privilegia o chamado "setor secundário" (halfway houses etc.) por oposição ao "primário" (prisões propriamente ditas); (d) a privatização tende a prevalecer nos Estados do Sul, tradicionalmente mais conservadores e com movimento sindical menos organizado do que os Estados do Norte; (e) as prisões privadas são mais comuns na esfera local do que na esfera estadual, entre outras razões porque as autoridades locais são mais permeáveis à pressão política.

A par disso, a implementação das prisões privadas tem despertado polêmica, especialmente no que respeita à promessa da eficiência e da redução dos custos e à constitucionalidade da delegação do poder de execução da pena às empresas. De um lado, o experimento concreto norteamericano e britânico tem demonstrado que as prisões privadas não vêm prestando serviços necessariamente mais baratos nem tampouco mais eficientes, reproduzindo os problemas estruturais que atravessam o sistema penitenciário público tradicional. Uma longa lista de práticas ineptas pode ser detectada nos dois contextos. De outro lado, essa reedição high-tech do panopticon benthamiano, sob o acicate da lógica da mercadoria, tende a colocar em questão alguns dos traços centrais do Estado de Direito, tais como o monopólio estatal do uso legítimo da força e o fundamento eminentemente público do poder nos regimes democráticos, dando lugar a objeções de ordem jurídica, política, ética e simbólica.

Os defensores da privatização têm freqüentemente manifestado o wishful thinking de que uma "fertilização cruzada" entre os setores público e privado poderia propiciar uma sinergia ótima capaz de fazer que uma esfera

9 Prison Reform Trust, "House of Commons Home Affairs Committee: Inquiry into the Management of the Prison Service (Private and Public)", Londres, maio de 1996, p. 06. 
aprendesse e se beneficiasse com a incorporação dos métodos e técnicas de gestão da outra. $\mathrm{O}$ que se observa na prática, porém, à medida que gradualmente a privatização se aproxima do "núcleo duro" do sistema prisional - o encarceramento de adultos -, é uma espécie de "fertilização cruzada" às avessas, em que mais e mais as prisões privadas se vêem às voltas com os mesmos problemas dos estabelecimentos públicos, notadamente a superpopulação, um regime disciplinar desumano e um contexto avesso às estratégias de reabilitação dos condenados, minando assim a promessa privatizante nos exatos termos em que vem sendo advogada. A esse respeito, é interessante verificar que na Inglaterra acaba de surgir o que se poderia considerar a última geração das técnicas de total quality management, ao menos quando adotadas pelos formuladores da política penitenciária: já há previsão legal para que os contratos firmados entre o setor público e o setor privado doravante possam incorporar uma cláusula permitindo a superpopulação de até $50 \%$ da capacidade do estabelecimento! 10

De modo geral pode-se dizer que tanto nos EUA quanto na GrãBretanha as prisões privadas têm operado em níveis muito aquém dos alardeados por seus defensores. No entanto, se não cumprem o que prometem, notadamente no que se refere aos objetivos internos do sistema de justiça criminal, como a diminuição da superpopulação e a reabilitação dos detentos, é certo que, paradoxalmente, elas se movem. O setor continua em franca expansão e as companhias têm ampliado largamente suas margens de lucratividade. Nos EUA, as prisões privadas já respondem por $4 \%$ do alojamento provido por todo o sistema. Em termos absolutos, isso significa algo como $40 \%$ da população penitenciária brasileira e a segunda população penitenciária da Europa ocidental.

\section{O NOVO CAMPO DE FORÇAS}

Se os principais fatos da história transcorrem — para falar como os clássicos - em dois tempos, na primeira vez como tragédia, na segunda como farsa, o ressurgimento das prisões privadas nos albores do terceiro milênio insere-se numa constelação histórico-social precisa, cujas tensões não resolvidas permitem ao mesmo tempo: (a) a restauração, ainda que

10 Cf. R. W. Harding, Private Prisons and Public Accountability. Buckingham: Open University Press, 1997, p. 123. 
burlesca, da grande promessa liberal-burguesa inscrita no modo como o discurso jurídico penal moderno concebe a pena privativa de liberdade, nomeadamente a articulação contraditória entre uma razão contratual e uma razão disciplinar, que reaparece no apelo simultâneo das prisões privadas à reabilitação dos condenados pelo trabalho produtivo e à incapacitação e ao justo merecimento; 11 (b) e a negação determinada dessa mesma promessa, nos exatos termos em que é formulada, o que paradoxalmente acaba possibilitando a atual voga de mercantilização do sistema penitenciário. De um lado, há continuidade, dada pela restauração e quebra da promessa embutida na penalidade moderna; de outro, descontinuidade, já que a expansão das prisões privadas ocorre a contrapelo do cumprimento de sua promessa como resultado de um novo conjunto de processos e práticas sociais. Detenho-me a seguir, brevemente, em três das linhas de força que configuram essa nova constelação histórica, o medo da violência, no campo simbólico-cultural, a ascensão da Nova Direita, no plano políticoinstitucional e a dinâmica do capitalismo global, na esfera econômica.

Do ponto de vista cultural, as prisões privadas parecem beneficiar-se largamente das incongruências que se verificam no modo como a violência tem sido apreendida simbolicamente e os tomadores de decisão procuram lhe fazer face. A imagem do cidadão crescentemente encurralado, conjugada a uma reorientação da política penal nos anos 80 e 90, que vai rifando o papel reabilitativo da prisão em nome da pura e simples inca-

11 A forma jurídica revestida pela moderna pena privativa de liberdade enreda-se numa contradição entre os pólos da retribuição (uma pena a ser imposta a partir de um exame estritamente lógico-formal acerca da ilicitude da conduta e da culpabilidade do agente) e da reforma (um cálculo utilitário destinado a prevenir a criminalidade e a reabilitar o condenado). A contradição é ideológica no sentido enfático, na medida em que se assenta numa aparência socialmente necessária assumida pelas relações sociais capitalistas, que, por sua vez, é transposta de modo peculiar para o discurso jurídico penal da modernidade. O princípio da recompensa equivalente medeia ao mesmo tempo relações jurídicas e econômicas. Ambas aparecem como relações que se travam num jogo de reciprocidade em que vontades individuais supostamente autônomas exercem o seu livre-arbítrio. A privação da liberdade juridicamente concebida como retribuição internaliza esse modo específico de aparecer que informa a esfera da circulação da sociabilidade capitalista (o que a forma jurídica revela). Porém, sob o fundo falso da reciprocidade, os institutos jurídicos e econômicos operam concretamente à base de gritantes desigualdades sociais. $\mathrm{O}$ outro da penalidade moderna pode ser identificado na instauração de um aparato técnico-disciplinar destinado ao controle das ilegalidades da força de trabalho e ao aprendizado, no cárcere, dos reclamos disciplinares do capitalismo fabril (o que a forma jurídica esconde). Desenvolvo esta questão em Laurindo Dias Minhoto, Privatização de presídios e criminalidade. A gestão da violência no capitalismo global. São Paulo: Max Limonad, 2000. 
pacitação dos detentos, pressionam sistematicamente em direção à adoção de políticas penais truculentas, o que, por sua vez, joga água no moinho da superpopulação penitenciária. Essa situação tem levado nos EUA (a) à formulação de políticas de sentenciamento mais restritivas pelo Legislativo, como por exemplo as sentenças mandatórias e determinadas, que contribuem para abarrotar ainda mais as prisões e, ao mesmo tempo, (b) à intervenção crescente do Judiciário no sistema visando a melhoria das condições de alojamento. Do lado do público, a grita por políticas penais autoritárias tem esbarrado na falta de apoio político para autorizar os gastos governamentais necessários à implementação do megaprojeto de construção de presídios. Capitalizando na zona cinzenta entreaberta pela sede de vingança, que repercute o senso comum criminológico do momento, ${ }^{12} \mathrm{e}$ pelas demandas de um Judiciário diligente, a nova banca penal aproveita para encher a burra.

Altas taxas de criminalidade, sensação generalizada de insegurança, a ideologia do "cidadão ultrajado", midiaticamente espetacularizada, uma guinada teórica em direção a um renovado "fez por merecer", just

12 O novo senso comum criminológico, produzido e reproduzido por setores dos sistemas político, acadêmico e midiático, comporta, de um lado, uma dimensão moralista-autoritária, segundo a qual "a grande fratura da nossa sociedade não é aquela que separa ricos e pobres, mas aquela que separa indivíduos capazes e incapazes de serem responsáveis por si mesmos" (Lawrence Mead, politicólogo conservador da Universidade de Nova Iorque), abrindo o caminho para a construção ideológica de uma underclass, constituída pelos setores da "desordem e da barbárie", e que opera a partir de um baralhamento das fronteiras entre criminalidade comum ou de varejo e a desobediência civil, a quebra do contrato social etc.; de outro, uma dimensão atuarial, graças à incorporação de práticas gerenciais e de técnicas da análise de sistemas à política de combate à criminalidade, no âmbito da qual a pesquisa operacional tende a substituir a sociologia como quadro cognitivo de referência e o discurso jurídico cede lugar progressivamente ao discurso da eficiência administrativa. De certo modo, do ponto de vista da criminologia hegemônica, não se trata mais de diagnosticar as causas da criminalidade, nem como conseqüência de prescrever um tratamento adequado ao criminoso em face de um esforço de contextualização do delito no âmbito da estrutura social, mas simplesmente de identificar, monitorar e segregar setores da população considerados de alto risco. O ideal reabilitativo que já constituiu o nervo das políticas penitenciárias do Welfare State sucumbe frente ao imperativo da segregação e da incapacitação. De passagem, note-se a privatização da idéia mesma de risco na sociedade contemporânea: assim como se migra da previdência pública para a previdência privada (do tratamento coletivo e social dos riscos para um tratamento administrativo e privado), migra-se da social net do Welfare para a drag net do sistema penal. No processo, as classes perigosas são redefindas como classes criminosas (Zygmunt Bauman, O mal-estar da pós-modernidade. Rio de Janeiro: Jorge Zahar, 1998, p. 57; sobre o novo senso comum criminológico, ver Christian Parenti, Lockdown America: Police and Prisons in the Age of Crisis. New York; Verso, 1999; Loic Wacquant, Les prisons de la misère. Paris: Raison d'Agir, 1999; Allessandro Di Giorgi, Zero Tolleranza, strategia e pratiche della società di controllo. Derive Approdi, 2000). 
deserves, práticas de sentenciamento mais rigorosas, a nova figura jurídica do "criminoso contumaz", o aperto na reincidência a partir do admirável three strikes and you are out (bordão do beisebol, que significa algo como três falhas seguidas no rebatimento da bola e o rebatedor está fora do time), truth in sentencing (estratégia de restrição ao regime de progressão das penas), proliferação de presídios de segurança máxima (the supermax option), programas de encarceramento de alto impacto para os jovens, mais conhecidos como boot camps, toque de recolher, limitações crescentes à prática da barganha judicial (plea bargain), à remição e ao livramento condicional, tolerância zero, enfim, estes são alguns dos ingredientes do caldeirão penitenciário contemporâneo, que, muito mais do que a improvável combinação de eficiência, produtividade e humanitarismo presente na pregação dos ideólogos, parecem estar de fato azeitando a máquina dos negócios correcionais do novo milênio.

No plano político-institucional, as prisões privadas ajustam-se perfeitamente ao projeto neoliberal de redução da presença do Estado na esfera do bem-estar e de ampliação das estratégias da lei e da ordem. Não por acaso, a política de privatização de presídios foi proposta no interior do vasto programa de privatização implementado pelas administrações Reagan e Thatcher. As políticas antiinflacionárias e as medidas de contenção do déficit público, justificadas pela reaganomics e pelo thatcherismo como estratégia para debelar a crise fiscal, têm convivido muito bem obrigado com o investimento maciço na repressão da criminalidade. Por trás do discurso de austeridade verifica-se um claro enviesamento político no modo como a crise fiscal do Estado tem sido administrada.

Subjacente a esse padrão enviesado de atuação estatal, pode-se observar o surgimento de um novo autoritarismo, em cujo âmbito o consenso interclassista do welfare tende a ser substituído por uma prática estatal bifronte, a um tempo mais autoritária em relação aos reclamos do populacho e extremamente diligente no atendimento às demandas do capital. ${ }^{13}$ Novo autoritarismo, aliás, muito providencial à construção ideológica da nova underclass, a ser devidamente monitorada pelo recurso reiterado aos meios repressivos. É precisamente neste ponto que o sentimento de insegurança notado acima e o novo autoritarismo parecem se encon-

13 Cf. Boaventura de Sousa Santos, Toward a New Common Sense. Londres: Routledge, 1995, pp. 277-278; Pela mão de Alice. Porto: Afrontamento, pp. 110-111. 
trar na encruzilhada de um clima da mais desabusada intolerância cultural, em que "livre mercado e sociedades cada vez menos livres vão de mãos dadas, com as inseguranças do primeiro sendo expressas de todos os modos possíveis nas formas de repressão que as convenções de hoje ainda permitem."14

Na esteira da ascensão da Nova Direita e da entronização da ortodoxia econômica neoclássica, bem como da panacéia privatizante que as acompanha, pode-se verificar a promoção de uma crescente deslegalização e desregulação dos direitos sociais e, no mesmo passo, a extensão do aparato de justiça criminal como estratégia privilegiada de controle das ilegalidades da nova underclass. A expansão contemporânea do Estado Penal constitui a contrapartida necessária do seu enxugamento na esfera social. A despeito das aparências, a guinada neoliberal continua a cavalgar o lombo surrado e tão amaldiçoado do Leviatã.

No entanto, o clima de intolerância e o novo autoritarismo só podem ser adequadamente apreendidos se localizados no quadro mais abrangente das transformações contemporâneas do capitalismo global, a terceira e decisiva linha de força a informar a expansão das prisões privadas na atualidade. Assim é que as metamorfoses do sistema econômico mundial, ao instituírem, em ritmo acelerado, miríades de situações e espaços de exclusão, abrem o caminho para o desenvolvimento de uma florescente indústria da miséria, que vem operando em escala crescentemente planetária. Num contexto de alta volatilidade financeira, reengenharia, downsizing, desemprego tecnológico, feminização e precarização do trabalho (minimum-wage "hamburger-flipping" jobs), fluxos migratórios desestabilizadores, desconstituição de direitos, neo-darwinismo social e o dramático aumento das desigualdades de renda, riqueza e poder, os efeitos devastadores do capitalismo turbinado constituem combustível altamente inflamável à conversão do controle dos novos párias em big business.

Com efeito, nas abarrotadas prisões contemporâneas, "a população potencialmente perigosa é apartada e alojada sob controle completo enquanto matéria-prima para o mesmo complexo industrial que a tornou supérflua fora da grades. Matéria-prima para controle ou, se se preferir, consumidores cativos dos serviços da indústria do controle."15 Fazer um 
fast buck às custas da "mais-população" devidamente descartada do novo jogo econômico que estrutura o capitalismo global parece constituir precisamente a lógica que preside à instauração contemporânea de um autêntico complexo comercial sócio-penal. ${ }^{16}$

Nos manuscritos conhecidos como Teorias da Mais-Valia, destinados à análise da história da teoria, Marx já assinalava o caráter produtivo do crime no modo capitalista de produção: "Um filósofo produz idéias, um poeta poemas, um pastor sermões, um professor tratados etc. Um criminoso produz crimes (...) $\mathrm{O}$ criminoso não produz somente crimes, ele produz também o Direito Penal e, em consequiência, também o professor que produz cursos de Direito Penal e, além disso, o inevitável tratado no qual este mesmo professor lança no mercado geral suas aulas como "mercadorias". (...) O criminoso produz, além disso, toda a polícia e toda a justiça penal, os beleguins, juízes, carrascos, jurados etc. (...) Enquanto o crime retira uma parte da população supérflua do mercado de trabalho e assim reduz a competição entre os trabalhadores (...) a luta contra o crime absorve outra parcela dessa mesma população (...) O crime, pelos meios sempre renovados de ataque à propriedade, dá origem a métodos sempre renovados de defendê-la e, de imediato, sua influência na produção de máquinas é tão produtiva quanto as greves." 17

$\mathrm{E}$ as prisões privadas podem então continuar a ser placidamente apresentadas como mais uma modalidade de gestão comunitária do sistema penitenciário, sob o manto diáfano da ideologia da eficiência e da racionalidade econômica, supostamente proporcionadas por uma generosa mão invisível, enquanto de fato estendem a mercantilização das práticas do controle penal contemporâneo.

\section{O NEGATIVO DO MODELO}

15 Nils Christie, Crime Control as Industry, op. cit., p. 118.

16 Por essa mesma razão, segundo Loic Wacquant, a passagem do Welfare State para um Estado Penal na cena contemporânea, longe de ser incompatível com o programa neoliberal de desregulamentação e desmonte do setor público, "revela o quadro verdadeiro, refletindo uma política de criminalização da pobreza que inevitavelmente anda em conjunto com a imposição de empregos inseguros e sub-remunerados e com a reestruturação dos programas de bem-estar", "From Welfare State to Prison State", Le Monde Diplomatique, Julho de 1998, p. 20.

17 Valho-me aqui da tradução do original feita por Vinicius Caldeira Brant em $O$ Trabalho Encarcerado. Rio de Janeiro: Forense, 1994, pp. 31 e 36, com acréscimos extraídos de K. Marx, "Apologist conception of the productivity of all professions", in M. Cain \& A. Hunt (eds) Marx and Engels on Law. Londres: Academic Press, 1979, pp. 191-192. 
No Brasil não se tem verificado, pelo menos na mesma intensidade, o reforço político-institucional do encarceramento atualmente em curso nos EUA e na Grã-Bretanha. De certo modo, a inflação carcerária medra entre nós a contrapelo do discurso governamental. ${ }^{18}$ De uma taxa de 62 detentos por 100 mil habitantes registrada em 1987, que nos colocava ao lado de um país como a Holanda, tradicionalmente parcimonioso no uso da prisão, pulamos já em 1994 para os 95 por 100 mil, quando enfim equiparamos a excelência dos níveis britânicos, apesar de, obviamente, continuarmos a amargar a poeira deixada pela vanguarda norte-americana. Atualmente, São Paulo lidera o ranking com seus impressionantes 175 detentos por 100 mil habitantes.

Num contexto de superpopulação, violência endêmica e condições absolutamente subumanas de alojamento, em que o estupro, o espancamento e os Carandirus fazem parte da paisagem, o Conselho Nacional de Política Criminal e Penitenciária (CNPCP), órgão do Ministério da Justiça encarregado da formulação de linhas diretrizes para a área, propõe formalmente, em janeiro de 1992, a adoção das prisões privadas no Brasil. Em sintonia com a confluência contemporânea entre discurso penitenciário e empresarial, a proposta, "oriunda de reflexões sobre as modernas e recentes experiências, que vêm sendo colocadas em prática em estabelecimentos prisionais dos Estados Unidos, da França, da Inglaterra e da Austrália", representaria "uma verdadeira retomada de sonhos", destinada, entre outras coisas, a "(a) atender aos preceitos constitucionais da individualização da pena e de respeito à integridade física e moral do preso; (b) lançar uma política ambiciosa de reinserção social e moral do detento, destinada a confiar nos efeitos da reabilitação e a refrear a reincidência; (c) introduzir, no sistema penitenciário, um modelo administrativo de gestão moderna; (d) reduzir os encargos e gastos públicos; (e) favorecer o desenvolvimento de salutar política de prevenção da criminalidade, mediante a participação organizada da comunidade nas tarefas de execução da pena privativa de liberdade; (f) aliviar, enfim, a dramática situação de superpovoamento no conjunto do parque penitenciário nacional"

18 Se bem que, no projeto de lei que acaba de ser elaborado pelo Ministério da Justiça, e que integra o Plano Nacional de Segurança Pública, o reforço da política de penas alternativas aparece simultaneamente à valorização da pena privativa de liberdade. Entre outras medidas, o governo propõe a extinção do sursis e da prisão albergue e a restrição do livramento condicional e do regime de progressão de penas. 
(minhas ênfases). ${ }^{19}$

Ainda que inegavelmente seja relevante questionar o retrato edulcorado do experimento internacional apresentado pelos defensores da privatização no Brasil, cumpre notar que o apelo das prisões privadas no contexto brasileiro parece derivar também de funcionalidades pouco explícitas a um padrão histórico autoritário de controle da violência.

Com efeito, a história política brasileira tem sido atravessada estruturalmente pelo uso continuado e generalizado da violência do aparato repressivo do Estado contra as classes sociais subalternas. ${ }^{20} \mathrm{~A}$ instrumentalização da violência do Estado com o fim de garantir o mando das classes proprietárias aparece no modo como a nossa "questão social" foi convertida em "caso de polícia". A onda de greves que marcou os conturbados anos 10 e 20, deflagrada sob os influxos da ideologia anarco-sindicalista - aportada ao país com a mão-de-obra imigrante -, e que denunciava as péssimas condições de trabalho da classe trabalhadora no período da "Revolução Industrial" brasileira, foi reprimida pelo recurso a práticas explicitamente truculentas.

A ideologia da subversão legitimava a expatriação de imigrantes "a escumalha social rejeitada pelas velhas civilizações da Europa", na dicção elegante das autoridades do período -, e o desterro (previsto na Constituição de 1891 , art. 80 , par. $2^{\circ}$.), pelo qual os "subversivos nacionais" eram deportados usualmente para a região Norte, num prolongamento dos tempos dos navios negreiros. ${ }^{21}$ Paulatinamente, a deportação e a ideologia da subversão foram apropriadas como práticas mais abrangentes de controle social e estendidas à repressão da mendicância e da desocupação nas zonas urbanas. Como

19 "Proposta de regras básicas para o programa de privatização do sistema penitenciário do Brasil", CNPCP, Brasília, 1992, pp. 01-02. Em grande medida, essa proposta resulta de um intenso lobby realizado por uma empresa brasileira de segurança privada, a Pires Segurança Ltda, objetivando transpor as prisões privadas para o contexto brasileiro a partir de uma manipulação seletiva da "experiência estrangeira", invocada como argumento de autoridade. Numa peça de garatuja publicitária, a Pires retoma a promessa de racionalização do sistema penitenciário, baseada na propaganda da eficiência e da produtividade ventilada por seus congêneres de além-mar, e se refere ao "exemplo americano da privatização" como um "movimento de opinião nacional", obscurecendo obviamente todos os traços problemáticos que circundam o atual debate sobre as prisões privadas nos EUA, cf. José Eduardo Faria, "Políticas públicas e privatização: o caso do sistema prisional", separata da Revista de Informação Legislativa, Senado Federal, 116, 1992, p. 117.

20 Cf. Paulo Sérgio Pinheiro, "Violência e cultura", in B. Lamounier et al. (eds), Direito, Cidadania e Participação. São Paulo: T A Queiroz, 1991, p. 52.

21 Id., Ibid., pp. 33-43. 
relata o historiador José Maria dos Santos, “a prisão policial, sem processo, por tempo indeterminado, agravada pela aplicação de sevícias corporais, ficou sendo o meio usual de incutir a boa conduta." 22 A porosidade das fronteiras entre a repressão política e o combate ao crime comum, marca do período, será reposta em momentos históricos subseqüentes e põe a nu a natureza política das estratégias de controle social no Brasil e sua centralidade ao mando das elites.

Nos períodos formalmente democráticos (1933-37 e 1945-64), o caráter visível da repressão é atenuado pela incorporação de parte da classe trabalhadora ao quadro institucional brasileiro, via regulação corporativista do conflito capital-trabalho, que se materializa na concessão paternalista de direitos sociais. A mitigação da "questão social" brasileira é levada a efeito às expensas da independência dos sindicatos pela criação da "cidadania regulada": cidadão é o trabalhador cujo direito é reconhecido pelo Estado, desde que tenha uma ocupação legalmente regulamentada. Na conhecida formulação de Wanderley Guilherme dos Santos, a cidadania é banida da esfera dos valores e da política e equiparada a um padrão corporativo de estratificação ocupacional. ${ }^{23}$

Durante o tempo da ditadura militar, sob a capa da "segurança nacional" - uma espécie de reedição da ideologia da subversão construída a partir da identificação de um "inimigo interno" - verifica-se uma extensão sem precedentes do poder da polícia militar. Em conseqüência, de lá para cá vem ocorrendo no Brasil um processo crescente de militarização do controle do crime, em que as estratégias de combate à criminalidade e de manutenção da ordem pública incorporam táticas mais apropriadas a operações de guerra.

A truculência policial brasileira deita raízes históricas bem fundas. A despeito de todas as mudanças ocorridas na fachada da instituição rótulos, títulos, discurso - a brutalidade permanece na passagem da

22 Citado em Paulo Sérgio Pinheiro, op. cit., p. 41.

23 Cf. Wanderley Guilherme dos Santos, Cidadania e justiça. Rio de Janeiro: Campus, 1979, p. 68. Esse refinamento das práticas de controle social não impediu, entretanto, o reforço simultâneo da estrutura repressiva do Estado. Na esteira da Revolução de 1930, foi criada a Delegacia Revolucionária de Ordem Política e Social, mantida até sua conversão, em 1938, no famigerado DOPS (Delegacia de Ordem Política e Social), como se sabe, largamente envolvido em práticas de tortura e execuções extrajudiciais no período da ditadura militar nos anos 60 e 70. Como observa argutamente Paulo Sérgio Pinheiro, no Brasil, "a legislação social serviu de certa forma para dissimular as pautas de violência ilegítima que permaneceram intocadas", in "Violência e cultura", cit., p. 50. 
Colônia à República. Como nota um respeitado analista, essa permanência deve-se, antes de mais nada, à continuidade fundamental na função disciplinar da polícia, e não só da polícia, diga-se de passagem, como também das cortes e do direito impessoal, instituições que, na sociedade brasileira, tendem a funcionar "não como salvaguarda dos direitos civis ou humanos, mas como instrumentos de repressão." 24

O sofrimento físico, como forma privilegiada de punição, constitui uma prática que remonta ao sistema policial dos tempos coloniais. À medida que funcionava como suplemento à coerção exercida pelo senhor de escravos, a instituição policial brasileira foi erigida com base na internalização da pletora de meios sanguinários empregados no período. $\mathrm{O}$ senhor de escravos, por sua vez, devidamente secundado pela carta de direitos incorporada à Constituição do Império e pelas conquistas do civilismo iluminista, como se sabe, podia usar, gozar e abusar de suas coisas do modo como melhor lhe aprouvesse. Ora, é precisamente essa inusitada combinação, a disparatada mistura entre direito burguês de propriedade e mão-de-obra escravista que permite entender o modo peculiar como se constitui e estrutura a instituição policial brasileira. A formação da polícia no Brasil mimetizou o esporão senhorial. Com a modernização incompleta e altamente desigual do país, o padrão selvagem de manutenção da ordem na senzala foi estendido ao controle dos homens livres e das classes subalternas.

Como resultado desse continuum histórico de práticas autoritárias de controle do crime e da violência, as prisões brasileiras têm sido, ao fim e ao cabo, depósitos inumanos das classes marginalizadas. Segundo o censo penitenciário de 1993, dois terços de nossos detentos são negros ou mulatos, $76 \%$ analfabetos ou semi-analfabetos, $98 \%$ não têm condições de contratar serviços de advocacia e nada mais nada menos que 95\% se encontram na faixa da pobreza absoluta.

Ora, é justamente à luz desse longo movimento histórico que se podem ler, com vantagem, as mudanças trazidas pela dinâmica perversa da cena contemporânea. No Brasil de hoje, verifica-se um processo crescente de "dualidade de poderes" que se vai sedimentando a reboque da expansão vertiginosa das empresas de segurança privada. Estima-se que tais empresas controlam atualmente um contingente de 550.000 agentes privados de segurança, virtualmente o dobro do efetivo das Forças Armadas. Um dos 
efeitos perversos da expansão das empresas de segurança privada no país é a constituição e o desenvolvimento de um sistema de segurança de duas camadas, pelo qual as elites brasileiras crescentemente se valem dos serviços privados, ficando o grosso da população submetido à truculência e ineficiência características da segurança pública. A face reversa desse mesmo processo aparece na emergência de uma rede paralela de controle social, catalisando a proliferação de chacinas, linchamentos e execuções extrajudiciais levados a efeito por justiceiros. Tais práticas têm se disseminado sobretudo nas zonas pobres e periféricas das grandes cidades, como as favelas, configurando uma autêntica privatização possessiva da justiça.

De outra parte, o medo da violência tem levado a uma privatização dos meios de segurança e a uma redefinição das fronteiras entre o público e o privado na sociedade brasileira. Da perspectiva do "andar de cima", esse processo favorece o surgimento de novos espaços e práticas de segregação social, tais como condomínios fechados, shopping centers, circuitos eletrônicos de monitoramento e vigilância em edifícios e residências, cancela nas ruas etc.; ${ }^{25}$ já da perspectiva do "andar de baixo", a proliferação de guetos violentos no espaço urbano contribui para que parcela significativa da população carente das grandes cidades, como Rio e São Paulo, encontre-se simplesmente privada do acesso a serviços básicos, tais como educação, correio, coleta de lixo e consumo. ${ }^{26}$

Não é fruto de outro contexto a mentalidade de sítio que caracteriza as nossas elites - à medida que o patriciado brasileiro se desconecta progressivamente dos problemas do país, tende a confirmar mais e mais a sua monumental aversão aos afogados -, detectada pelo comentário lúcido e sempre mordaz de Luis Fernando Verissimo, para quem seria possível visualizar todos os nossos apartheids numa imagem só: "a de condomínios de luxo cercados, com metralhadoras nas guaritas, e todas as casas com antenas suplicantes viradas para o céu, pegando sitcoms e outros sinais de civilização superior, enquanto da escuridão em volta só se ouvem os sons

\footnotetext{
25 Para uma análise desse processo e suas implicações para a incipiente democracia no Brasil, ver Sérgio Adorno, A gestão urbana do medo e da insegurança. Violência, crime e justiça penal na sociedade brasileira contemporânea, Tese de Livre-Docência apresentada ao Departamento de Sociologia da FFLCH da USP, 1996; Teresa Caldeira, City of walls: crime, segregation and citizenship in São Paulo, Tese de Doutoramento, Berkeley, Universidade da California, 1992; Antônio Luiz Paixão, "Segurança privada, direitos humanos e democracia", Novos Estudos, Cebrap, 31, 1991, pp. 131-142.

26 Cf. Folha de S. Paulo, 16.02.97, p. 3-1.
} 
de programas de auditório e outras distrações primitivas que, pelo menos, impedem os bárbaros de pensar e atacar."27

Cumpre referir ainda, a título de complementação desse trágico cenário, o baixo grau de confiabilidade dos brasileiros na Justiça - entendida como locus institucional de mediação de conflitos em sociedades democráticas -, aferido por recente pesquisa do IBGE. Nada menos que $67 \%$ das pessoas envolvidas em conflitos de natureza trabalhista, cível e criminal não recorreram à Justiça. O principal motivo alegado foi "resolveu por conta própria" (42\%), o que parece confirmar a violência como padrão de resolução de conflitos intersubjetivos.

Tudo parece convergir portanto para o acerto da tese da permanência do autoritarismo socialmente implantado no Brasil de hoje, em que "a transição democrática, após vinte um anos de regime autoritário (1964-1985), não foi suficiente para submeter as agências encarregadas da repressão ao crime ao império da lei." 28 As estratégias de resolução de conflitos baseadas numa lógica privada que chancela a violência como padrão de comportamento usual figuram no centro de uma sociabilidade autoritária.

Decididamente, um autoritarismo bem plantado em nossa história. Para retomar uma vertente seminal dos estudos clássicos sobre a formação da sociedade brasileira, a "mistura entre coisa pública e negócios privados" - que permite a personalização do desempenho das funções públicas e desautoriza a norma geral - entreabre claramente o qüiproquó constitutivo da nossa sociabilidade. Entre nós, o mercado e o Estado constituem-se a partir, e não, como seria de se esperar, a despeito das relações de dominação pessoal, expressas numa mentalidade senhorial e numa cultura do favor profundamente enraizadas no país, que, porém, à vista de sua coexistência contraditória com o travo capitalista, tendem a se redefinir no interesse das práticas de otimização das oportunidades lucrativas. ${ }^{29}$

É precisamente essa dinâmica social específica que tem permitido e fomentado o desenvolvimento entre nós de um autêntico código do sertão, que corre às costas dos princípios jurídicos de normalização da con-

27 Luis Fernando Verissimo, "Novo Apartheid" (2), O Estado de S. Paulo, 25.06.1999, p. A4.

28 Sérgio Adorno, A gestão urbana do medo e da insegurança, op. cit., p. 40.

29 A respeito, ver Sérgio Buarque de Holanda, Raízes do Brasil. Rio de Janeiro: José Olympio, 1994 (1936) e Maria Sylvia de Carvalho Franco, Homens livres na ordem escravocrata. São Paulo: Ática, 1974. 
duta, subtraindo-lhe eficácia e sancionando as práticas violentas como modelo de conduta socialmente válido e positivamente valorado. Num mundo feito antes de mais nada de pessoas e não de abstrações, em que a Justiça não consegue se afirmar, a violência entranha-se na realidade social, impregnando as relações comunitárias nos níveis de vizinhança, trabalho, lazer, parentesco e moralidade. Nesse universo, atravessado por uma grande conflituosidade social, a maior capacidade de violência dos sujeitos é decisiva. As regras impessoais do direito cedem lugar recorrentemente aos princípios de autoridade do passado e os usos e costumes acabam reforçando a apropriação privada das prerrogativas policiais e judiciárias. ${ }^{30}$

Portanto, no âmbito da constituição dialética da sociabilidade brasileira, não se trata simplesmente de justapor, lado a lado, uma "sociedade tradicional", em que as relações sociais são reguladas a partir da dominação pessoal, e uma "sociedade moderna", organizada a partir da impessoalidade, da abstração etc. Antes de mais nada, aqui na Belíndia para retomar um cânon do dualismo estanque -, os traços "antigos" tendem a ser incorporados e redefinidos pela emergência do "moderno", configurando uma situação contraditória, em que um não existe sem o outro, dando lugar à constituição recíproca de ambos numa unidade de contrários. $^{31}$

Na esteira dessa tradição teórica, Roberto Schwarz tem refletido sobre o lado perverso da prática reiterada e acrítica de importação de soluções institucionais supostamente modernas (como parece ser o caso das prisões privadas). Entre nós, o incessante fluxo de formas pode acabar, paradoxalmente, repondo, expandindo e reforçando traços autoritários característicos do nosso Antigo Regime. No entanto, o decisivo é que esta reposição não aponta apenas para a permanência do "atraso" na sociedade brasileira, constituindo, antes, a face "moderna" que a periferia assume no âmbito do desenvolvimento desigual e combinado do sistema capitalista contemporâneo. ${ }^{32}$

Para falar como nosso autor — mais uma vez adiada a perspec-

30 Maria Sylvia de Carvalho Franco, op. cit.

31 Id., ibid.

32 Cf. Roberto Schwarz, "Um seminário de Marx”, in Seqüências Brasileiras. São Paulo: Companhia das Letras, 1999; “As idéias fora do lugar”, in Ao vencedor as batatas. São Paulo: Duas Cidades, 1977; "Nacional por subtração", in Que horas são? São Paulo: Cia. das Letras, 1987. 
tiva de síntese entre o padrão civilizatório e a deformação local - tem se verificado atualmente no Brasil uma espécie de "desautorização recíproca" entre o privado tomado como índice de uma sociabilidade autoritária e o privado tomado como ideologia da eficiência, que, no entanto, se entrecruzam na constituição de novos limites à possibilidade de implementação de um controle efetivamente democrático da violência no país, reatualizando entre nós, ao que parece, o Estado de Direito como "lamentável mal-entendido".

No Brasil privatizado de hoje, um país cada vez mais permeado por práticas neovigilantes, igualmente mobilizadas pelos happy few e pelos restless many, que proliferam à sombra da falência do aparato de controle social do Estado, sob o império do tráfico e de outras modalidades de gestão empresarial da miséria, configurando um quadro dramático de crescente privatização possessiva da justiça - "o outro sentido trágico da privatização do público operada no Brasil" 33 -, o apelo das prisões privadas não parece residir apenas em sua auto-apresentação como panacéia supostamente eficiente para o enfrentamento da crise do sistema penitenciário, nos termos da ortodoxia ideológica neoliberal. Antes, o fascínio pela privatização parece derivar também de sua funcionalidade a um continuиm de práticas autoritárias formais e informais do controle da violência, do crime e da punição, que demandam soluções privadas como extensão e reposição de um processo histórico preexistente que - em tempo de capitalismo global — teima em reinscrever por aqui as marcas da barbárie.

LAURINDO DIAS MINHOTO é doutor em Filosofia e Teoria Geral do Direito pela USP e autor de Privatização de presídios e criminalidade. A gestão da violência no capitalismo global (Max Limonad, 2000).

33 Francisco de Oliveira, "Privatização do público, destituição da fala e anulação da política: o totalitarismo neoliberal", in Francisco de Oliveira e Maria Célia Paoli (orgs.) Os sentidos da democracia. Políticas do dissenso e hegemonia global. Petrópolis: Vozes, 1999, p. 74. 